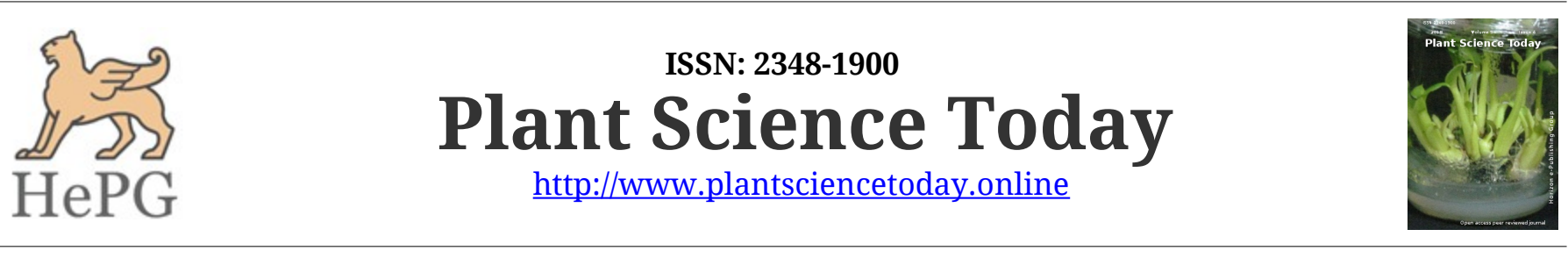

OPEN ACCESS

Research Article

\title{
The role of Garo tribes of Meghalaya (India) in the conservation and management of medicinal plants diversity used in treating livestock diseases
}

\author{
${ }^{1}$ D. B. Sangma, ${ }^{* 2}$ T. N. Manohara \\ ${ }^{1}$ Rain Forest Research Institute, Jorhat, Assam 785001, India \\ ${ }^{2}$ Institute of Wood Science and Technology, Bengaluru 560 003, India
}

\section{Article history}

Received: 15 August 2018 Accepted: 20 September 2018

Published: 02 October 2018

\section{Editor}

Dr. Shahina A Ghazanfar, Royal Botanic Gardens, Kew, Richmond, United Kingdom

\section{Publisher \\ Horizon e-Publishing Group}

\author{
*Correspondence \\ T. N. Manohara \\ $\triangle$ manohara tn@yahoo.com
}

\begin{abstract}
The Garo tribe of Meghalaya, India have rich local health traditions and large numbers of traditional healers have been practicing herbal medicines for many years. The present study aims at quantifying the plant species used for ethno-veterinary purposes and to identify their conservation status. Out of 90 informants 22 were traditional healers and 68 were farmers. A total of 75 ethnoveterinary medicinal plant species belonging to 71 genera and 49 families were documented and identified for treating 24 different livestock ailment. Most of the medicinal plants (83\%) were collected from the wild and leaves were the most frequently used (58\%) parts for formulation of drugs; oral application is most frequently employed (56\%), followed by the dermal application which accounts for $31 \%$. The medicinal plants collected are mostly trees (31\%), followed by herbs (25\%). The study indicates that some species are rare or endangered and their use is therefore unsustainable. The strategies for effective conservation of endangered medicinal plant are discussed here.
\end{abstract}

\section{Keywords}

Chinawood; Endangered; Ethnoveterinary; Traditional healers; West Garo Hills

\begin{abstract}
Citation
Sangma D B, Manohara $\mathrm{T}$ N. The role of Garo tribes of Meghalaya (India) in the conservation and management of medicinal plants diversity used in treating livestock $\begin{array}{llll}\text { diseases. Plant } & \text { Science } & \text { Today } & \text { 2018;5(4):155-162. }\end{array}$
\end{abstract} https://dx.doi.org/10.14719/pst.2018.5.4.416

\section{Introduction}

Medicinal plant and traditional knowledge occupies an important position in the socio-cultural, spiritual and medicinal arena of rural and tribal lives of India (1). There is a strong use of traditional knowledge-based home remedies for primary health care for humans as well as for the livestock using plant resources. The number of medicinal plants in India, both indigenous and introduced has been estimated to be between 3,000 to 3,500 species of higher plants (2). About 2,500 plants have been reported to be used in ethno-medicine (3). The State of Meghalaya, India has a diverse topography, altitude 


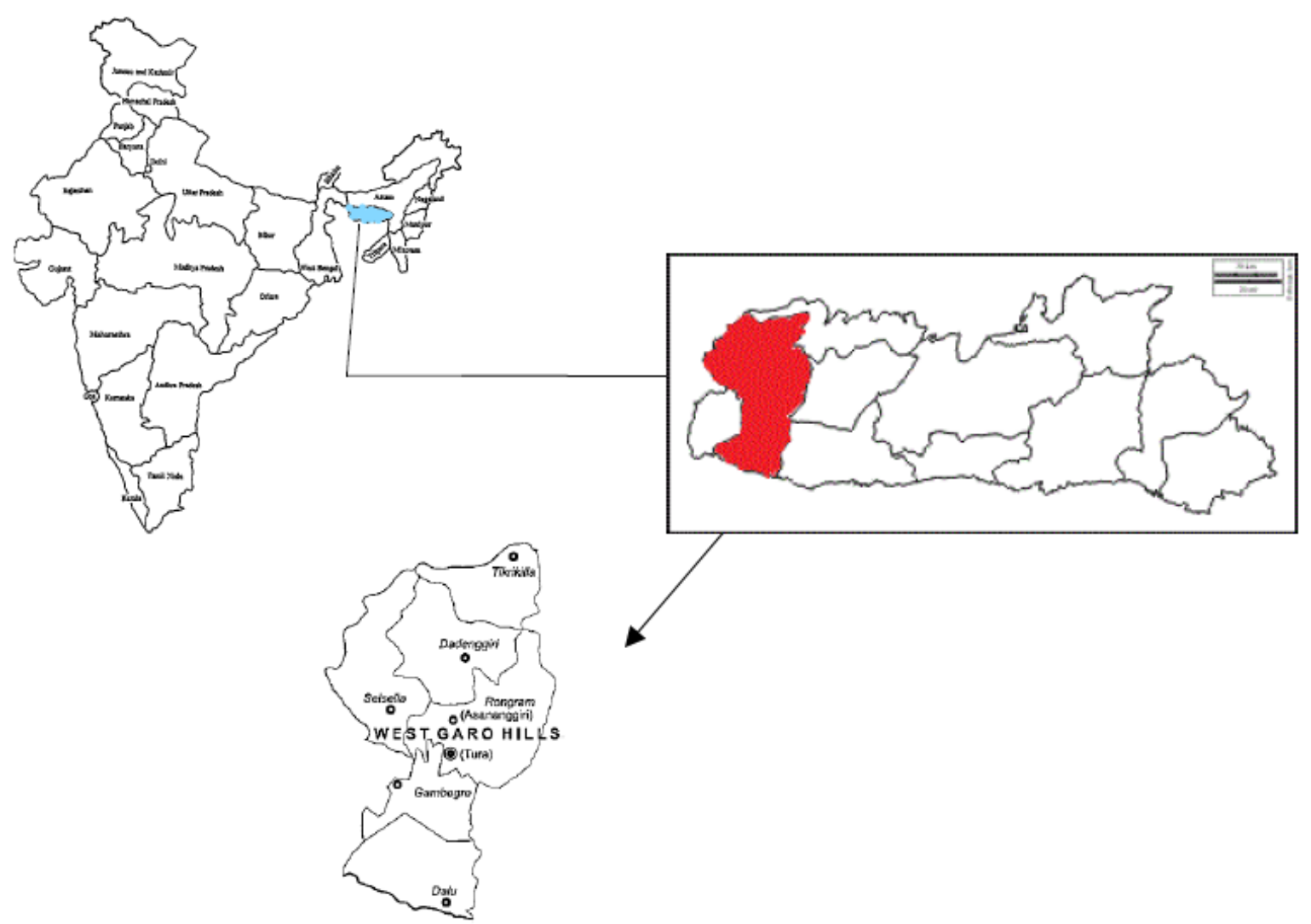

Fig. 1. Map of the study area

and climatic conditions (4). It is home to a unique array of vegetation, ranging from tropical and subtropical to temperate or near temperate (5). More than 200 forest plants are used by the people of Meghalaya for food, medicines, dyes and for ornamental and construction of houses (6). The Ethno-medicines and medicinal plants of Meghalaya have received some attention of researchers $(7,8,9)$. The study conducted was to document the ethnobotanical values and taxonomic aspect of the species.

For the Garo tribe of Meghalaya, medicinal plants are as important as the food they eat everyday; and they cannot survive without herbal medicines which are consumed both as preventive as well as for curing specific common ailments for themselves and their livestock. The Garo tribe have rich local health traditions and a large number of traditional healers have been practising herbal medicine for many generations. The reliance on traditional medicine is most common in remote areas. This is due to a number of factors (i) the financial constraints of farmers in getting their livestock treated with modern medicines; (ii) the lack of health care centres in nearby areas; (iii) poor road network and transportation. Ethnoveterinary medicine (EVM), on the other hand, is easily available, cheaper, causes no side effects and can be prepared easily without the use of modern technology. An important drawback of EVM is the fact that, ethnoveterinary medicinal plant knowledge like other forms of traditional knowledge is passed verbally from generation to generation and there is very likely a loss of precious information (10). It is therefore essential to document and conserve both the medicinal plants and the associated indigenous knowledge as these, could provide future drugs to cure some of the important diseases of animals. Most villages in the Garo Hills district have some tracts of dense and well protected patches of community owned primary forests referred as 'community forests' or 'community conservation areas' (Sacred groves). The conservation of different types of forests is part of community conservation practices, which have evolved over centuries and passed down from generation to generation. These forests are valuable for the ecosystem in terms of protection of the upper catchments of watersheds, conservation of biodiversity and medicinal plants. The rising commercial demand for herbal drugs, unsustainable harvest and increased dependency on wild resources has led to the rapid depletion of several medicinal plant species. Currently, there is no scientific system of plant collection or regeneration as a result of which many of the medicinal plants have become endangered. The sustainable management of these traditionally used plants will help to conserve national and global biodiversity, as well as it will provide natural resources to improve livelihoods.

\section{Materials and Methods \\ Description of the study area}

The Garo Hills are part of the Garo-Khasi range in Meghalaya, India (Fig. 1). The Garo Hills district encompasses five districts namely, West Garo 
Hills, East Garo Hills, South Garo Hills, North Garo Hills and South-West Garo Hills. The district is situated between the latitudes $90^{\circ} 30^{\prime}$ and $89^{\circ} 40^{\prime} \mathrm{E}$ and the longitudes of $26^{\circ}$ and $25^{\circ} 20^{\prime} \mathrm{N}$ forming the western part of the State, the entire Garo Hills having an area of approximately $8000 \mathrm{sq} \mathrm{kms}$ is densely forested and hence one of the richest spots in biodiversity. The climate of the district is largely controlled by South-west monsoon and seasonal winds and temperature ranges from $22^{\circ} \mathrm{C}$ to $30^{\circ} \mathrm{C}$ for most part of the year. The average rainfall in the district is $807 \mathrm{~mm}$. (11). The vegetation consists mostly of dense tropical mixed forest, and a small patch of temperate forest in the higher parts of the Tura range. The total livestock population in West Garo Hills is $6,72,358$ and poultry population is $8,17,566$ (12).

\section{Sampling and Data Collection}

The study was carried out in 6 selected villages of two C\&RD Block of (Dalu and Dadenggiri) West Garo Hills, namely Chigitchakgre, Sadolpara, Rondupara, Renginpara, Kujikura and Tibapara (Fig. 1). The study sites were selected based on the availability of traditional healers identified with the assistance of community leaders, elderly people and village headman. Field work was done from August to December 2017. Prior Information Consent (PIC) was obtained from the community and village headman (Nokma) before carrying out the study. A total of 90 informants were selected and interviewed based on their knowledge on traditional medicine. Out of 90 informants 22 were traditional healers and 68 were farmers (13). Each person was interviewed separately in local language using semi-structured questionnaires. Interviewees were asked about the type of animal they rear, the number of plants they use to treat the livestock, type of livestock ailments they treat, plant parts used, formulation and mode of administration of ethnoveterinary medicine (14).

\section{Collection and Preservation of the Reported Medicinal Plants.}

Field visits were made with local informants to collect the medicinal plants reported. Collected plants were identified using different floras (15) and consulting herbarium voucher specimens at the Botanical Survey of India, Shillong, Meghalaya. The prepared herbariums were deposited at the Rain Forest Research, Institute, Jorhat, Assam, for future reference.

The conservation status of medicinal plants were determined based on the information given by the villagers and field observations and reviewing the available literature $(16,17,18)$ (Supplementary Table 1).

\section{Analysis of data}

The collected ethnoveterinary medicinal data was organized using descriptive statistics and the percentiles, figures and tables were used to summarize the collected data. Preference ranking was computed (19). Informant consensus (IFC) is used to recognize widely used medicinal plants for the treatment of specific ailments. Informant Consensus Factor values were determined as recommended by Heinrich et al. (20).

$$
\mathrm{ICF}=\mathrm{Nur}-\mathrm{Nt} /(\mathrm{Nur}-1)
$$

Where,

Nur: Number of use reports for a particular use category

Nt: Number of taxa used for a particular use category by all informants

\section{Results}

Relationship between usage of ethnoveterinary medicine, literacy rate and distance from urban centres

Literacy and distance were respectively correlated to the usage of ethnoveterinary medicine. Correlation between usage and literacy is - 0.68 which is a negative relation and it indicates that there is no relation between literacy and usage of traditional medicine. The standard error is 0.369 and t-test value calculated is 0.446 which is insignificant when compared with the standard ' $\mathrm{t}$ ' value at $5 \mathrm{df}$. Since the relation is very weak, it can be said that they are not related.

However, there was a significant positive correlation (Pearson correlation coefficient, $r=$ 0.91 , at $\alpha=0.05, p=0.01$ ) between the usage $\%$ and distance from the urban centres. The standard error for this correlation coefficient is 0.590 and the calculated t-test is 0.0001 which is significant when compared with the standard 't' value at $5 \mathrm{df}$.

\section{Medicinal Plants Reported}

A total of 75 ethnoveterinary medicinal plant species belonging to 71 genera and 48 families were documented with details on route of administration, mode of preparation, plant part used, habit, habitat, family name, scientific name and local name (Supplementary Table 1). Araceae had a relatively high number of species with a total number of $5(10.2 \%)$ plant species, followed by Lamiaceae with 4 (8.1\%) species, then Poaceae, Euphorbiaceae, Lauraceae and Rutaceae with 3 (6.1\%) species, Gesneriaceae, Amaranthaceae, Convolvulaceae, Menispermaceae, Polypodiaceae and Malvaceae had $2(4 \%)$ species and the rest 37 families had 1 (2\%) species each (Fig. 2).

\section{Habitat of Medicinal Plants}

In the study area, the majority of the medicinal plants were collected from the wild (83\%) and the remaining from home gardens (17\%) (Fig. 3).

\section{Plant Parts Used for EVM}

Both mature and young leaves (58\%) were used in preparation of ethnoveterinary medicine (EVM) 


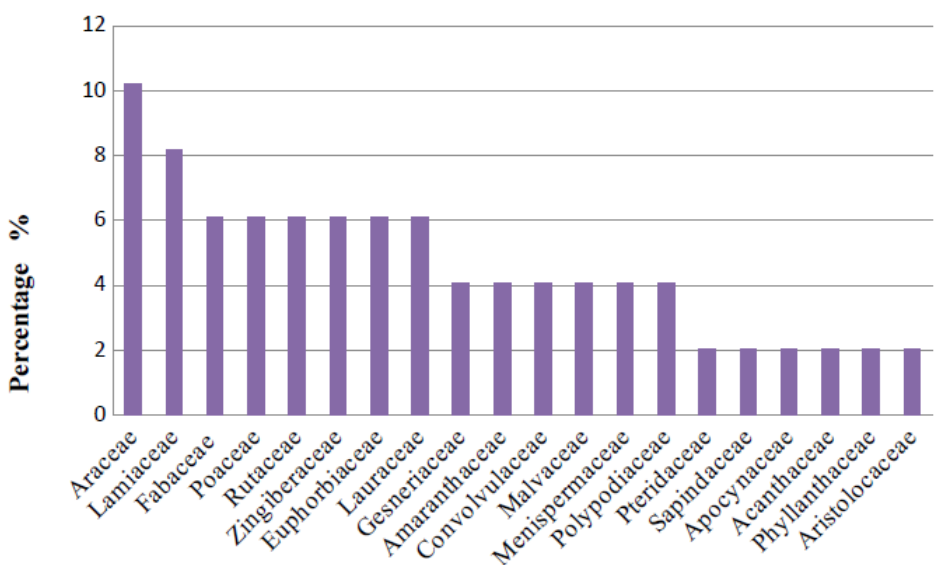

Fig. 2. Family distribution of medicinal plants

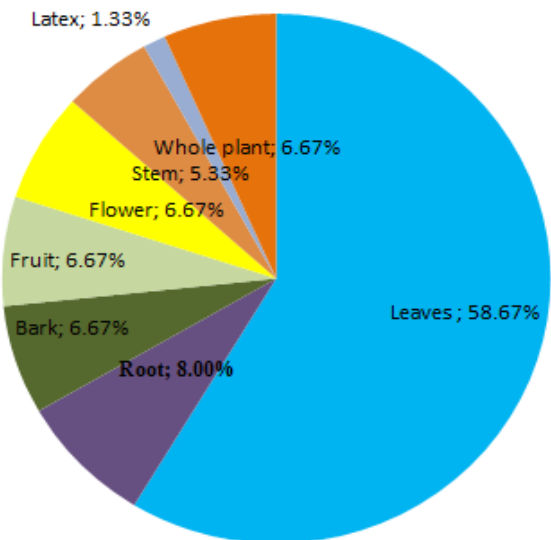

Fig. 4. Percentage of plant parts used in the treatment of livestock diseases

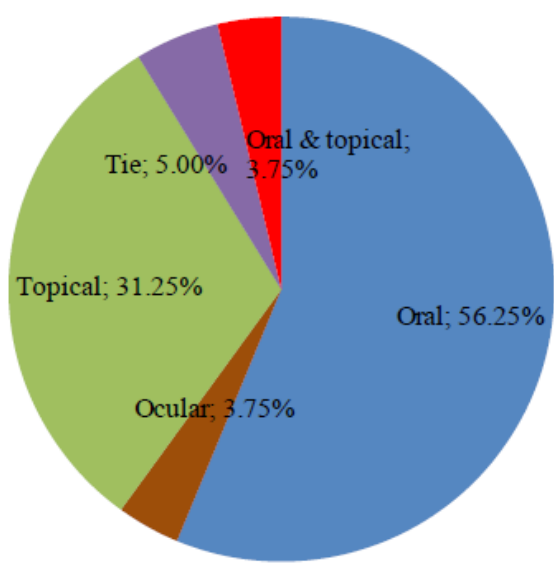

Fig. 5. Percentage of route of administration

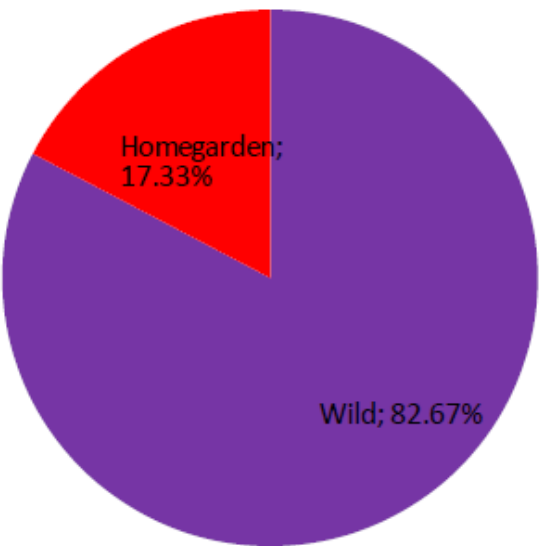

Fig. 3. Percentage of medicinal plants on the basis of their habitats

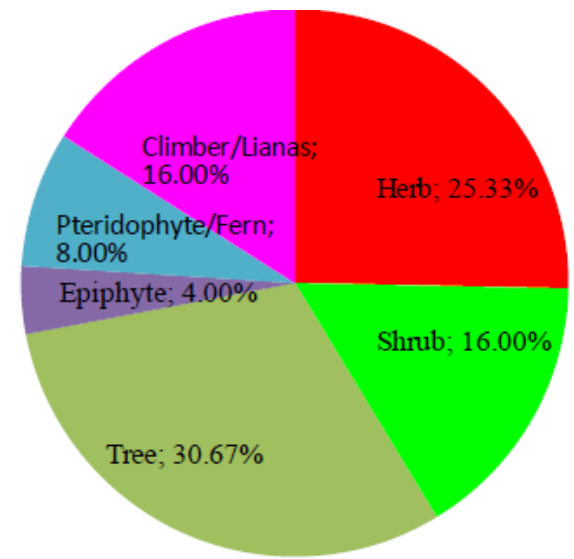

Fig. 6. Habit of the reported medicinal plants followed by roots (8\%). In some formulation of EVM whole plant is also used (Fig. 4).

\section{Mode of Administration}

The major modes of administration in the study area were oral, topical, tie-on and ocular. Oral administration was most often used (56\%), followed by topical application (31\%), and tie-on method (5\%). In the tie-on method plants are tied around the neck of the animal till the disease is cured or the plants dry up. In some treatment both oral and topical methods are followed (4\%) (Fig. 5).

\section{Habit of the Medicinal Plants}

Most of the medicinal plants were trees (31\%), followed by herbs (25\%), shrubs (16\%), climbers (16\%), pteridophytes (8\%) and epiphytes (4\%) (Fig. 6).

\section{Informant Consensus Factor (ICF)}

In the study area the ailments with high ICF value of 1 , each were arthritis, rabies, reproductive diseases, retained placenta and swollen body parts (Table 1).

\section{Threats to Medicinal Plants}

A series of group discussions and interviews conducted in different areas in addition to observations revealed that a majority of the species are faced with a number of threats. Deforestation, followed by agricultural expansion and over harvesting is the major threats for the medicinal plants in the study area (Table 2).

\section{Medicinal Plant Conservation Efforts of the Local People}

A majority of informants (60\%) were found to collect and harvest fresh medicinal plants from the wild as their need arose. Other informants (40\%) were aware of the importance of conserving medicinal plant species, practiced conservation activities such as cultivating some plant species in home gardens - this initiative was a result of the difficulties they experienced in collecting the plants from the wild.

\section{Discussion}

Agriculture is the main occupation for the rural community of the study area, they also depend on livestock rearing as a source of secondary income. The Garo tribe of Meghalaya make use of a large variety of medicinal plants available to them (Fig 7A-E). The present study revealed that people of the region use 75 medicinal plants for treatment of common livestock diseases and trees form the major source of medicinal plants (Table 1). A 
Table 1. Informant Consensus Factor of ethnoveterinary medicinal plants by ailment groups

\begin{tabular}{|c|c|c|c|c|}
\hline Sl. No. & Ailment category & No. of species & Species (\%) & $\begin{array}{c}\text { Citations relating } \\
\text { to use }\end{array}$ \\
\hline
\end{tabular}

\begin{tabular}{|c|c|c|c|c|c|}
\hline 1 & Arthritis & 1 & 1.3 & 20 & 1 \\
\hline 2 & Blood clot/bleeding & 4 & 5.3 & 24 & 0.86 \\
\hline 3 & Centipede bite & 1 & 1.3 & 36 & 1 \\
\hline 4 & Constipation & 5 & 6.6 & 41 & 0.9 \\
\hline 5 & Diarrhoea & 7 & 9.3 & 39 & 0.92 \\
\hline 6 & Ecto-parasites & 4 & 5.3 & 39 & 0.92 \\
\hline 7 & Eye infection & 4 & 5.3 & 40 & 0.89 \\
\hline 8 & Fever & 5 & 6.6 & 28 & 0.88 \\
\hline 9 & Foot and mouth diseases & 4 & 5.3 & 38 & 0.91 \\
\hline 10 & Fracture/sprain & 4 & 5.3 & 31 & 0.96 \\
\hline 11 & Gallstone & 2 & 2.6 & 14 & 0.76 \\
\hline 12 & Indigestion/bloating & 4 & 5.3 & 45 & 0.86 \\
\hline 13 & Loss of appetite & 2 & 2.6 & 37 & 0.97 \\
\hline 14 & Mouth ulcer & 2 & 2.6 & 39 & 0.97 \\
\hline 15 & Nerve diseases/limpness & 2 & 2.6 & 20 & 0.94 \\
\hline 16 & Rabies & 1 & 1.3 & 10 & 1 \\
\hline 17 & Reproductive diseases & 1 & 1.3 & 29 & 1 \\
\hline 18 & Respiratory diseases & 5 & 6.6 & 37 & 0.88 \\
\hline 19 & Retained placenta & 1 & 1.3 & 27 & 1 \\
\hline 20 & Skin diseases & 6 & 8 & 50 & 0.89 \\
\hline 21 & $\begin{array}{l}\text { Snake poisoning/plant } \\
\text { poisoning }\end{array}$ & 4 & 5.3 & 21 & 0.85 \\
\hline 22 & Swine fever & 3 & 4 & 26 & 0.92 \\
\hline 23 & Swollen body part & 1 & 1.3 & 28 & 1 \\
\hline 24 & Wounds & 2 & 2.6 & 47 & 0.97 \\
\hline
\end{tabular}

Table 2. Threats to medicinal plants in the study area

\begin{tabular}{|c|c|c|}
\hline Sl. No. & Factors & Respondent percent (\%) \\
\hline 1 & Deforestation & 25.56 \\
\hline 2 & Jhum cultivation/ agricultural expansion & 22.23 \\
\hline 3 & Land slides & 11.12 \\
\hline 4 & Human settlement & 21.12 \\
\hline 5 & Over harvesting & 13.34 \\
\hline 6 & Over grazing & 6.67 \\
\hline
\end{tabular}

wider use of Araceae family followed by Lamiaceae, Fabaceae and Poaceae was reported in the study area (Fig 2). Cows and buffaloes were the most commonly treated animals followed by swine and poultry birds in the studied region. They treat their animal based on the symptoms of disease. 


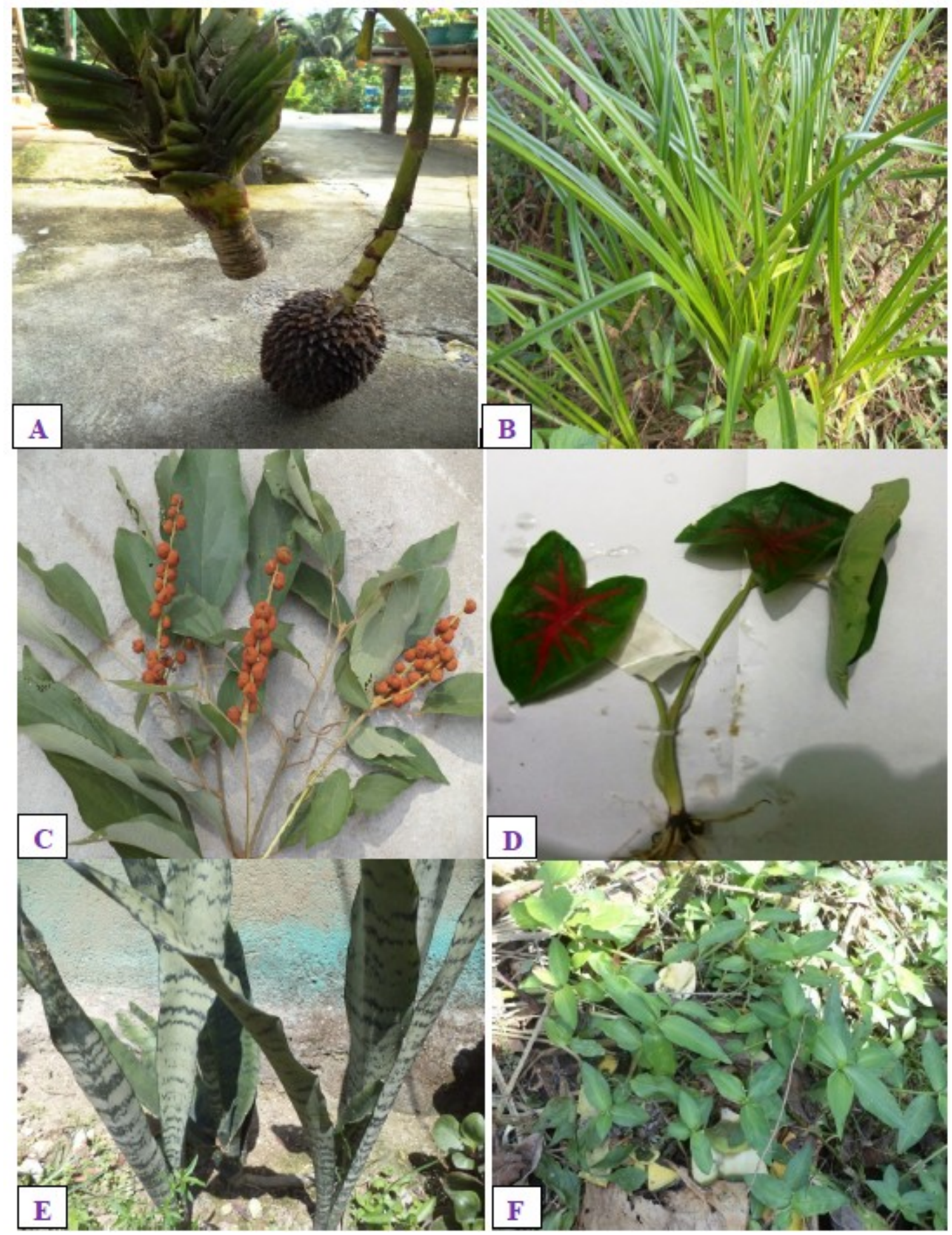

Fig. 7. Medicinal plants used in EVM by Garo Tribe. A. Pandanus odoratissimus (Screw palm) B. Carex cruciata (Cruciate sedge) C. Mallotus philippensis (Red kamala) D. Caladium bicolour (Elephant ear) E. Sansevieria trifasciata (Viper's bowstring hemp) F. Murdannia nudiflora (Doveweed).

Some of the diseases mention by farmers and traditional healers in this study indicate symptoms of disease only. Therefore it is difficult to distinguish between diseases and symptoms of diseases when compared with western veterinary medicine system. The ethnoveterinary formulations in the study area are prepared mostly using leaves of plants. They preferred leaves in formulation of EVM because it is easier to collect as compared to other plant parts. The second most widely used form in the study area is root. Collecting of root is not a sustainable type of harvesting as compared to leaves. Leaves harvesting does not pose any major damage to the plant life cycle as compared to collecting of roots. It was observed that a single plants as well as combination of many plants and plant parts were administered to cure a number of ailments in animals. It was seen a single herbal recipe is effective for treatment of different ailments, which showed that a single plant is used for more than one ailment. The most preferred mode of administration of drug was oral followed by topical application. In some cases, both topical and oral methods were used. Oral administration was used because most of the ailments were internal. These medicines were administered to the animal along with water, salt, feed, oil etc. Dosage of 
ethnoveterinary medicine was not uniform and varied depending on the severity of animal diseases.

Most of the people of the study area collect and harvest fresh medicinal plants from the wild as their need arose and are not bothered about their long-term survival. But a few people use to cultivate the medicinal plants in their home gardens as they experienced difficulties in collecting them from wild. The over exploitation of medicinal resources in an unscientific manner by unskilled individual is forcing many of the species into the verge of extinction such as Aconitum ferox (Indian Aconite), Aquilaria malaccensis (Agarwood), Garcinia pedunculata (Bor thekera), Smilax glabra (Chinaroot), Taxus wallichiana (Himalayan yew) and Valeriana hardwickii (Indian valerian).

\section{Conclusion}

Traditional health-care system is age old practice performed since ancient times by the tribal people of Garo Hills. The traditional knowledge is mostly held by healers and elderly individuals. The younger generation is unaware of these traditional uses because of their inclination towards allopathic medicine. Therefore, they should be encouraged in ethnoveterinary practices in order to conserve this knowledge. The pharmacological screening of these plants would give the information in regard to the true remedial activity to cure common animal ailments. Hence, intensive ethnobotanical and phytochemical studies are very much needed in the region to bring out more useful information. Medicinal plants are still collected from the wild. As most of these medicinal plants are experiencing threat, ex-situ conservation of cultivating in home gardens, botanical and medicinal plant gardens will help in protecting the endangered species. Therefore, there is an immediate need to take necessary steps for the conservation of these highly utilized ethnoveterinary medicinal plants before their extinction.

\section{Competing Interests}

We declare that we do not have competing interests.

\section{Authors contribution}

DBS executed the field work and compiled the data and TNM conceptualized the work plan and structured the manuscript.

\section{Acknowledgements}

The authors are grateful to the Director, RFRI, Jorhat for the facility and encouragement. Thanks are due to the staff of BSI Shillong for helping in plant identification. Thanks are due to the Department of Animal Husbandry and Veterinary, Shillong and Tura, Meghalaya and College of Veterinary Science, Khanapara, Guwahati, Assam for providing statistical data and other valuable information. The authors are also thankful to the local informants for sharing their valuable knowledge. We thank the anonymous reviewers for their careful reading of our manuscript and insightful comments and valuable suggestions.

\section{References}

1. Gupta S, Porwal M C, Roy P S. Indigenous knowledge on some medicinal plants among the Nicobari Tribe of Car Nicobar Island. Indian Journal of Traditional Knowledge 2004; 3(3):287293.

2. Asolkar L V, Kakkar K K, Charke O J. Second supplement to glossary of Indian medicinal plants with active principles Part-I (A-K) (19651981) New Delhi, India: Publication and Information Directorate (CSIR); 1992.

3. Jain S K. Dictionary of Indian folk Medicine and Ethnobotany. Deep Publications, New Delhi; 1991.

4. Das T, Samajdar T, Islam M, Singh N A, Marak G. Traditional farming system: A Case Study of Garo Tribe in West Garo Hills District of Meghalaya, North-Eastern India. International Journal of Agriculture Sciences 2016; 8(50):21402145.

5. Kharbuli B, Syiem D, Kayang H. Biodiversity: North East India Perspectives. North Eastern Biodiversity Research Cell, Shillong, Meghalaya, India; 1999.

6. Tiwari B K, Tynsong H. Biodiversity Enriching and Livelihood Enhancing Practice of NTFP, MP and MAP Management of War Khasi of Meghalaya, India. Final Technical Report. IDRCMAPPA Project, Centre for Environmental Studies, NEHU, Shillong; 2004.

7. Rao R R. Ethnobotanical study of the flora of Meghalaya: Some reports of herbal medicines. Jain S. K. (Ed) Glimpses of Indian Ethnobotany Oxford IBH Publishing co. New Delhi; 1981. Pp:137-146.

8. Dolui A K, Sharma H K, Marein T B, Lalhriatpuii T. Folk herbal remedies of Meghalaya. Indian Journal of Traditional Knowledge 2004; 3:58-64.

9. Sangma D B, Manohara T N. Ethnoveterinary practices of Garo tribes from West Garo Hills district of Meghalaya, India: perspective and future prospects. Journal of Traditional and Folk Practices 2017; 5(2):21-36.

10. Awas T. Plant Diversity in Western Ethopia: Ecology, Ethnobotany and Conservation. PhD Dissertation, Faculty of Mathematics and Natural Sciences, University of Oslo, Norway; 2007. 
11. District statistical Handbook. Directorate of Economics \& Statistics, Government of Meghalaya, Shillong; 2014.

12. State at a glance: Meghalaya, 2016. http://gbpihedenvis.nic.in/State_at_glance/Megh alaya\%20Glance/Meghalaya at a glance.pdf.

13. Tariq A, Mussarat S, Adnan M, AbdElsalam N M, Ullah R, Khan A L. Ethnoveterinary Study of Medicinal Plants in a Tribal Society of Sulaiman Range. The Scientific World Journal 2014; http:// dx.doi.org/10.1155/2014/127526.

14. Tariq A, Adnan M, Mussarat S. Use of Ethnoveterinary Medicines by the People Living Near Pak-Afghan Border Region. Slovenian Veterinary Research 2016; 53(3): 119 - 30.

15. Haridasan K, Rao R R. Forest flora of Meghalaya, Vol 1 \& 2. Bishen Singh Mahendrapal Singh: Dehradun; 1985-1987.
16. Nayar M P, Sastry A R K. Red data book of Indian plants. Vol. I. Howrah, Botanical Survey of India, 1988.

17. Nayar M P, Sastry A R K. Red data book of Indian plants. Vol. I. Howrah, Botanical Survey of India, 1989.

18. Nayar M P, Sastry A R K. Red data book of Indian plants. Vol. I. Howrah, Botanical Survey of India, 1990.

19. Martin J. Ethnobotany: A Methods Manual. Chapman and Hall, London; 1995. https://doi.org/10.1007/978-1-4615-2496-0

20. Heinrich M, Ankli A, Frei B, Weimann C, Sticher O. Medicinal plants in Mexico: Healer's Consensus and Cultural Importance. Social Science and Medicine 1998; 47:1863-1875. https://doi.org/10.1016/S0277-9536(98)00181-6 